\title{
PENGGUNAAN PUZZLE UNTUK MENINGKATKAN MOTIVASI BELAJAR SISWA KELAS 4 SD PADA MATA PELAJARAN PAI
}

\author{
KHOLIS ANJALEKA \\ SD Negeri 2 Kalibagor Situbondo \\ e-mail: kholisanjaleka@gmail.com
}

\begin{abstract}
ABSTRAK
Penelitian ini bertujuan untuk meningkatkan motivasi belajar siswa kelas 4 SD Negeri 2 Kalibagor Situbondo dengan penggunaan media pembelajaran puzzle. Jenis penelitian ini adalah Penelitian Tindakan Kelas (PTK) yang dilaksanakan sebanyak 2 siklus, dimana tiap siklusnya dilakukan sebanyak 2 kali pertemuan. Subyek penelitian ini adalah siswa kelas 4 SD Negeri 2 Kalibagor Situbondo semester ganjil tahun pelajaran 2021/2022 yang berjumlah 9 anak, 6 laki-laki dan 3 perempuan. Hasil penelitian ini menunjukkan bahwa motivasi belajar siswa dengan penggunaan media pembelajaran puzzle secara klasikal terjadi peningkatan dari 5 anak $(56 \%)$ pada siklus 1 menjadi 8 anak (89\%) pada siklus 2 . Tingginya motivasi belajar siswa mempengaruhi peningkatan ketuntasan belajar siswa, yaitu dari 4 anak (44\%) pada siklus 1 menjadi 8 anak (89\%) pada siklus 2. Dengan demikian dapat disimpulkan bahwa penggunaan puzzle dapat meningkatkan motivasi belajar siswa kelas 4 SD Negeri 2 Kalibagor Situbondo tahun pelajaran 2021/2022 pada mata pelajaran Pendidikan Agama Islam (PAI).
\end{abstract}

Kata Kunci: Penggunaan Puzzle, Motivasi Belajar

\section{PENDAHULUAN}

Keberhasilan proses pembelajaran di kelas dipengaruhi oleh beberapa faktor, baik yang berasal dari lingkungan siswa maupun dari dalam dirinya. Salah satu faktor yang sangat mempengaruhi yang berasal dari dalam diri siswa adalah motivasi belajar. Dimana dengan adanya motivasi belajar yang tinggi pada siswa, mereka akan bersungguh-sungguh dalam mengikuti proses pembelajaran yang berlangsung di kelas. Siswa yang memiliki motivasi belajar akan bersungguh-sungguh dalam melakukan kegiatan belajar, seperti menyimak isi pelajaran, mencatat pelajaran, bertanya ketika ada pelajaran yang belum dipahami, dan mengerjakan tugas yang diberi guru. Sedangkan siswa yang tidak memiliki motivasi belajar umumnya akan cepat merasa jenuh dalam mengikuti proses pembelajaran. Mereka tidak akan bertanya meskipun pelajaran yang disampaikan guru tidak dipahami. Dan mereka akan sembarangan dalam mengerjakan tugas-tugas yang diberikan guru. Bahkan ada sebagian dari mereka yang mengantuk disaat proses pembelajaran berlangsung.

Motivasi belajar merupakan suatu dorongan atau pemberian semangat kepada siswa atau peserta didik agar lebih aktif dalam proses pembelajaran untuk mencapai prestasi belajar yang baik (Prawira, 2013: 320). Motivasi belajar memiliki pengaruh yang sangat tinggi terhadap proses dan hasil pembelajaran. Motivasi belajar dapat menumbuhkan gairah, semangat dan rasa senang dalam belajar. Siswa akan lebih lama bertahan dalam mengikuti proses pembelajaran, sehingga mereka bisa menjadi siswa yang berprestasi (Masrohatin, 2013: 13). Munculnya motivasi belajar dipengaruhi faktor instrinsik dan ekstrinsik. Faktor instrinsik yaitu berupa hasrat dan keinginan siswa untuk berhasil dan dorongan dalam dirinya akan kebutuhan belajar, serta harapan akan tercapainya cita-cita. Dan faktor ekstrinsik yang turut mempengaruhi munculnya motivasi belajar adalah penghargaan dari guru, lingkungan belajar siswa yang kondusif, dan kegiatan belajar yang menarik bagi siswa. Motivasi belajar dapat mempengaruhi prestasi belajar siswa. Jika motivasi belajar tinggi, prestasi belajar akan baik, dan ketika motivasi belajar kurang, prestasi belajar kurang memuaskan (Harisuddin, 2019: 5).

Salah satu usaha guru untuk menumbuhkan motivasi belajar siswa adalah menggunakan metode dan kegiatan yang beragam. Metode atau kegiatan yang menoton akan menimbulkan kebosanan dan menurunkan semangat belajar siswa. Guru dituntut untuk selalu mencoba sesuatu yang berbeda dengan menggunakan metode yang bervariasi dalam proses pembelajaran 
di kelas (Lestari, 2020: 15). Oleh sebab itu, seorang guru harus selalu mengamati keadaan siswanya setiap menggunakan metode pembelajaran, agar dapat diketahui apakah metode tersebut dapat meningkatkan motivasi belajar siswa apa tidak. Indikator motivasi belajar siswa yang dapat diamati adalah; 1) durasi kegiatan yang mampu diikuti, 2) frekuensi kegiatan yang dilakukan dalam waktu tertentu, 3) ketabahan, keuletan, dan kemampuan dalam menghadapi rintangan dan kesulitan untuk mencapai tujuan kegiatan , 4) tingkat aspirasi dalam kegiatan, 5) tingkat prestasi yang dicapai, dan 6) sikap suka atau tidak suka terhadap sasaran kegiatan (Harisuddin, 2019: 29-30).

Berdasarkan pengamatan peneliti selama proses pembelajaran PAI di kelas 4 SD Negeri 2 Kalibagor S1itubondo, siswa terlihat sering terlihat melamun. Ketika diberi waktu untuk bertanya tentang pelajaran PAI yang belum dimengerti tidak ada satupun yang bertanya. Bahkan mereka kebingungan ketika diberi soal-soal PAI. Disaat mengerjakan tugas kelompok, tiap kelompok hanya satu anak yang serius mengerjakannya. Anggota kelompoknya hanya diam tidak ikut berpartisipasi dalam mengerjakan tugasnya. Pelajaran PAI yang disuruh tulis, mereka tulis. Namun ketika ditanyakan tentang pelajaran yang ditulisnya mereka kebingungan tidak bisa menjawabnya. Mereka sebagian besar tidak semangat mengikuti kegiatan pembelajaran. Bahkan ketika proses pembalajaran sudah berlangsung lama, ada salah satu siswa yang mengantuk di dalam kelas. Untuk mengurangi kejenuhan mereka, peneliti mengangkat sebuah kisah yang berhubungan dengan materi pelajaran. Sebagian banyak mereka mendengarkan kisah tersebut. Namun ketika ditanya pesan pokok yang ada dalam kisah tersebut mereka tidak bisa menjawabnya. Mereka hanya tertarik mendengarkan kisahnya saja, bukan mencermati pelajaran yang terkandung di dalamnya. Mereka cenderung pasif dan tidak mau berfikir.

Dari hasil pengamatan tersebut dan berdasarkan hasil diskusi dengan teman sejawat, dapat diketahui bahwa permasalahan yang terjadi di kelas 4 SD Negeri 2 Kalibagor Situbondo adalah siswa kurang memiliki motivasi belajar. Sehingga dibutuhkan sebuah metode atau media pembelajaran yang dapat menumbuhkan motivasi belajar pada diri siswa. Mengingat mata pelajaran PAI khususnya aspek tauhid berisi wahyu Ilahi dan sunah rasul yang bersifat mutlak dan berada di luar jangkauan akal dan indera manusia, maka peneliti mencoba mencari strategi baru yang cocok dengan materi tersebut agar proses pembelajaran tidak membosankan. Selain itu, strategi baru tersebut juga bisa melatih siswa untuk menggunakan fikirannya dalam proses pembelajaran. Sehingga siswa berperan aktif dan semangat mengikuti kegiatan belajar yang berlangsung di dalam kelas. Alternatif yang ditawarkan peneliti untuk mengatasi masalah siswa tersebut adalah penggunaan media pembelajaran puzzle dalam menyajikan materi beriman kepada Allah dan rasul-Nya.

Puzzle berasal dari bahasa inggris yang artinya bongkar pasang (Agustia dkk, 2021: 13). Media puzzle merupakan salah satu media pembelajaran yang sederhana, dimana cara bermainnya dengan bongkar pasang (Sunarti \& Dalle, 2017: 19). Media pembelajaran puzzle tidak sulit bagi guru dalam pembuatannya, serta mudah digunakan oleh siswa. Penggunaan media pembelajaran puzzle dapat menjadikan siswa lebih aktif dalam mengikuti proses pembelajaran. Selain itu, manfaat penggunaan media pembelajaran puzzle bagi siswa diantaranya dapat melatih konsentrasi siswa, ketelitian dan kesabaran siswa, serta memperkuat daya ingat pada siswa (Neteria, Mulyadiprana, \& Respati, 2020: 89).

\section{METODE PENELITIAN}

Jenis penelitian ini adalah Penelitian Tindakan Kelas (PTK). Tahapan pelaksanaan penelitian ini ada empat tahap, yaitu perencanaan, pelaksanaan, pengamatan, dan refleksi. Tahapan-tahapan tersebut dilaksanakan sebanyak 2 siklus, dimana tiap siklusnya dilakukan sebanyak 2 kali pertemuan dengan durasi tiap pertemuan 2 x 35 menit. Subyek penelitian ini adalah siswa kelas 4 SD Negeri 2 Kalibagor Situbondo dengan jumlah siswa 9 anak yang terdiri dari 6 siswa laki-laki dan 3 siswa perempuan. Penelitian ini dilakukan di bulan Agustus 
semester ganjil tahun pelajaran 2021/2022 pada mata pelajaran Pendidikan Agama Islam (PAI) materi beriman kepada Allah.

Kegiatan guru atau peneliti pada tahap perencanaan meliputi; (1) Mendiskusikan masalah siswa dengan kepala sekolah; (2) Membuat Rencana Pelaksanaan Pembelajaran (RPP); (3) Membuat media pembelajaran puzzle; (4) Menyiapkan lembar observasi tentang motivasi belajar siswa; dan (5) Menyusun soal tes materi beriman kepada Allah. Pada tahap pelaksanaan, langkah-langkah guru yang dilakukan yaitu; (1) Memberikan penjelasan singkat tentang materi beriman kepada Allah; (2) Membagi siswa menjadi beberapa kelompok kecil; (3) Membagikan media pembelajaran puzzle; (4) Menjelaskan tata cara penggunaan media pembelajaran puzzle; (5) Menyuruh semua kelompok untuk memasang dan menjodohkan kepingan-kepingan puzzle yang berisi penjelasan ke papan puzzle yang berisi pernyataan-pernyataan sehingga membentuk kalimat yang benar; (6) Menyuruh semua kelompok maju bergantian ke depan kelas untuk mempresentasikan hasil kerjanya; (7) Memandu siswa dalam menyimpulkan pelajaran; (8) Memberikan soal tes kepada siswa; dan (9) Menilai lembar kerja siswa.

Pada tahap pengamatan, guru memantau kegiatan belajar siswa selama proses pembelajaran berlangsung dan mengisi lembar observasi motivasi belajar siswa. Kemudian hasil pengamatan dan nilai lembar kerja siswa tersebut dianalisis oleh guru untuk mengetahui berhasil tidaknya masalah penelitian ini teratasi. Pada tahap refleksi guru menetapkan tindakan apa yang harus dilakukan berdasarkan hasil pengamatan. Pada siklus 1 proses dan hasil pembelajaran masih belum sesuai dengan yang diharapkan. Sehingga guru melakukan perbaikan dalam merencanakan dan melaksanakan pembelajaran pada siklus 2. Sedangkan pada siklus 2 proses dan hasil pembelajaran sudah sesuai dengan yang diharapkan. Sehingga guru menghentikan penelitian ini.

\section{HASIL PENELITIAN DAN PEMBAHASAN}

Hasil

Hasil penelitian dalam PTK ini diperoleh dari hasil pengamatan dan nilai lembar kerja siswa. Pengamatan motivasi belajar siswa dilakukan dengan cara mengamati sikap dan perilaku siswa selama mengikuti proses pembelajaran dan mengisi instrumen lembar observasi. Hasil pengamatan motivasi belajar siswa dicantumkan dalam tabel berikut.

Tabel 1. Hasil Pengamatan Sikap dan Perilaku Siswa

\begin{tabular}{|c|c|c|c|c|c|}
\hline \multirow{2}{*}{ No. } & \multirow{2}{*}{ Aspek yang diamati } & \multicolumn{2}{|c|}{ Siklus 1} & \multicolumn{2}{|c|}{ Siklus 2} \\
\hline & & Jumlah & $\%$ & Jumlah & $\%$ \\
\hline 1 & $\begin{array}{l}\text { Siswa disiplin dalam mengikuti proses } \\
\text { pembelajaran }\end{array}$ & 5 & $56 \%$ & 8 & $89 \%$ \\
\hline 2 & Siswa berpartisipasi dalam tugas kelompok & 4 & $44 \%$ & 8 & $89 \%$ \\
\hline 3 & Siswa serius memperhatikan penjelasan guru & 5 & $56 \%$ & 7 & $78 \%$ \\
\hline 4 & Siswa semangat dalam menyelesaikan tugas & 6 & $67 \%$ & 9 & $100 \%$ \\
\hline 5 & Siswa serius menyelesaikan tugas kelompok & 4 & $44 \%$ & 7 & $78 \%$ \\
\hline \multicolumn{2}{|r|}{$\begin{array}{l}\text { Jumlah rata-rata siswa yang memiliki motivasi } \\
\text { belajar }\end{array}$} & 5 & $56 \%$ & 8 & $89 \%$ \\
\hline
\end{tabular}

Untuk mengukur keberhasilan proses pembelajaran yang telah dilakukan, guru memberikan soal tes tentang materi beriman kepada Allah. Hasil belajar siswa disajikan dalam tabel berikut.

Tabel 2. Distribusi Hasil Belajar Siswa

\begin{tabular}{clcc}
\hline No. & \multicolumn{1}{c}{ Uraian } & Siklus 1 & Siklus 2 \\
\hline 1 & Nilai Tertinggi & 80 & 100 \\
2 & Nilai Terendah & 50 & 60 \\
3 & Nilai Rata-rata Siswa & 63,33 & 85,56 \\
4 & Jumlah Siswa yang Tuntas & 4 & 8
\end{tabular}


5 Jumlah Siswa yang Belum Tuntas $\quad 5 \quad 1$

6 Persentase Ketuntasan Belajar Siswa $\quad 44 \% \quad 89 \%$ berikut.

Perbandingan hasil belajar siswa antara siklus 1 dan siklus 2 disajikan pada diagram

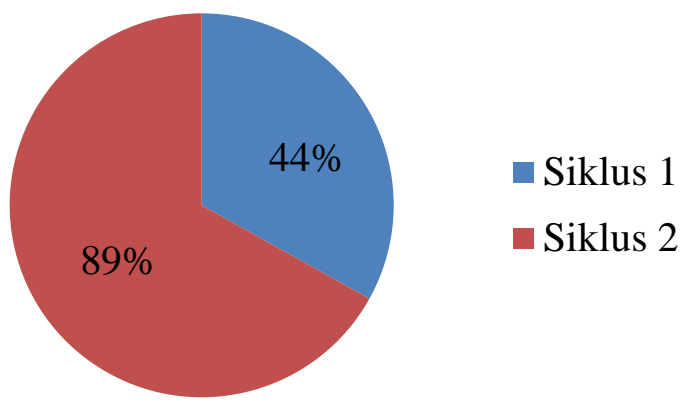

\section{Gambar 1. Perbandingan Hasil Belajar Siswa}

\section{Pembahasan}

Berdasarkan tabel 1 hasil pengamatan sikap dan perilaku siswa pada siklus 1 diketahui bahwa siswa yang disiplin dalam mengikuti proses pembelajaran 5 anak, siswa yang berpartisipasi dalam tugas kelompok 4 anak, siswa yang serius memperhatikan penjelasan guru 5 anak, siswa yang semangat dalam menyelesaikan tugas 6 anak, dan siswa yang serius menyelesaikan tugas kelompok 4 anak. Indikator-indikator ini dijadikan acuan oleh peneliti untuk mengukur motivasi belajar siswa. Sebagaimana pendapat Maryanto, Setyowani, dan Mugiarso (2013: 4) bahwa motivasi belajar siswa dapat diketahui dengan beberapa ciri, yaitu gigih mengerjakan tugas dan menghadapi kesulitan, mempunyai semangat belajar yang tinggi, senang memecahkan masalah, dan memiliki keinginan bergabung dalam sebuah kelompok.

Berdasarkan hasil pengamatan tersebut, motivasi belajar siswa pada siklus 1 secara klasikal masih kurang. Siswa kurang termotivasi karena mereka masih kebingungan menggunakan media pembelajaran puzzle. Hal ini disebabkan mereka baru pertama kali menggunakan media tersebut. Selain itu, juga ditemukan beberapa siswa tidak serius melakukannya. Mereka menganggap permainan tersebut hanya permainan biasa yang tidak akan dinilai oleh guru. Akibat kurangnya motivasi belajar pada diri siswa, hasil belajar siswa juga kurang baik. Dari tabel 2 distribusi hasil belajar siswa dapat diketahui bahwa secara klasikal pada siklus 1 siswa yang tuntas hanya 4 anak (44\%) sedangkan 5 anak ada masih belum tuntas.

Setelah melakukan pengamatan pada siklus 1, peneliti memutuskan untuk melanjutkan penelitian pada siklus 2 dengan rencana perbaikan-perbaikan untuk menyelesaikan masalahmasalah yang ditemukan pada siklus 1. Adapun rencana perbaikan yang dirumuskan oleh peneliti adalah guru akan menjelaskan dengan detail cara memainkan media pembelajaran puzzle dan akan memberitahukan kepada siswa bahwa hasil permainan tersebut berpengaruh terhadap nilai siswa.

Pada siklus 2 peneliti mengulang kembali pelaksanaan proses pembelajaran yang dilakukan pada siklus. Namun pelaksanaan tersebut diterapkan pada materi PAI lanjutan dari materi sebelumnya dengan melakukan perbaikan-perbaikan yang telah direncanakan pada siklus 1. Berdasarkan tabel 1 hasil pengamatan sikap dan perilaku siswa pada siklus 2 diketahui bahwa siswa yang disiplin dalam mengikuti proses pembelajaran 8 anak, siswa yang berpartisipasi dalam tugas kelompok 8 anak, siswa yang serius memperhatikan penjelasan guru 7 anak, siswa yang semangat dalam menyelesaikan tugas 9 anak, dan siswa yang serius menyelesaikan tugas kelompok 7 anak.

Berdasarkan hasil pengamatan tersebut, motivasi belajar siswa secara klasikal terjadi peningkatan, dari 5 anak (56\%) pada siklus 1 menjadi 8 anak (89\%) pada siklus 2 . Hal ini 
menunjukkan bahwa penggunaan media pembelajaran puzzle dapat meningkatkan motivasi belajar siswa. Hasil penelitian ini sesuai dengan hasil kajian perpustakaan yang dilakukan oleh Suratiningsih (2021: 25), dimana menurutnya penggunaan media puzzle akan membuat siswa berfikir kreatif. Siswa akan semakin tertantang untuk menyelesaikan permainan tersebut. Sehingga mereka tidak akan cepat bosan mengikuti proses pembelajaran yang berlangsung di dalam kelas. Hasil penelitian ini juga sejalan dengan hasil penelitian yang dilakukan oleh Mariana (2014: 85), dimana dalam kesimpulan penelitiannya menyatakan bahwa media pembelajaran puzzle dapat meningkatkan motivasi belajar siswa.

Tingginya motivasi belajar pada diri siswa mempengaruhi ketuntasan belajar siswa. Hal ini ditunjukkan pada tabel 2 distribusi hasil belajar siswa, dimana ada peningkatan ketuntasan belajar siswa dari 4 anak (44\%) pada siklus 1 menjadi 8 anak (89\%) pada siklus 2. Satu anak yang belum tuntas sebenarnya sudah ada peningkatan hasil penilaiannya yaitu yang awalnya mendapat nilai 50 pada siklus 2 mendapat nilai 60. Namun nilai tersebut masih dibawah nilai Kriteria Ketuntasan Minimal (KKM) mata pelajaran PAI yang telah ditetapkan yaitu 70. Hal ini sesuai dengan hasil penelitian yang dilakukan oleh Saputra, Ismet, dan Andrizal (2018: 29) yang menyatakan bahwa motivasi belajar memiliki pengaruh positif yang sangat kuat terhadap hasil belajar siswa.

Dari hasil penelitian pada siklus 2 dapat diketahui bahwa masalah dalam penelitian ini sudah teratasi atau dengan kata lain tujuan penelitian ini sudah tercapai. Sehingga peneliti memutuskan untuk menghentikan penelitian ini.

\section{PENUTUP}

Berdasarkan hasil penelitian dan pembahasan diketahui bahwa dengan penggunaan puzzle dalam proses pembelajaran, motivasi belajar siswa meningkat dari $44 \%$ pada siklus 1 menjadi $89 \%$ pada siklus 2 . Oleh sebab itu, peneliti menyimpulkan bahwa penggunaan puzzle dapat meningkatkan motivasi belajar siswa kelas 4 SD Negeri 2 Kalibagor Situbondo tahun pelajaran 2021/2022 pada mata pelajaran Pendidikan Agama Islam (PAI).

Penulis merekomendasikan kepada rekan-rekan guru untuk melakukan penelitian sejenis dengan subjek yang berbeda. Penulis juga mengharap kepada para pembaca akan kritikan dan masukan yang membangun demi kesempurnaan artikel ini.

\section{DAFTAR PUSTAKA}

Agustia, S. L. dkk. (2021). Inovasi Media Pembelajaran SD Berbasis Kearifan Budaya Lokal. Kediri: CV Srikandi Kreatif Nusantara.

Harisuddin, M. I. (2019). Secuil Esensi Berpikir Kreatif \& Motivasi Belajar Siswa. Bandung: PT. Panca Terra Firma.

Lestari, E. T. (2020). Cara Praktis Meningkatkan Motivasi Siswa Sekolah Dasar. Yogyakarta: Deepublish.

Mariana, D. (2014). Puzzle sebagai Media Pembelajaran untuk Meningkatkan Motivasi Belajar Siswa TK Budi Rahayu Yogyakarta. Skripsi. Program Studi Pendidikan Seni Kerajinan Fakultas Bahasa Dan Seni Universitas Negeri Yogyakarta.

Maryanto, L., Setyowani, N., \& Mugiarso, H. (2013). Meningkatkan Motivasi Belajar Siswa melalui Layanan Penguasaan Konten dengan Teknik Bermain Peran. Indonesian Journal of Guidance and Counseling: Theory and Application. Vol. 2. No. 3. dari http://journal.unnes.ac.id/sju/index.php/jbk.

Masrohatin, K. (2013). Pengaruh Model Pembelajaran Kooperatif Tipe TSTS (Two Stay Two Stray) terhadap Peningkatan Motivasi dan Prestasi Belajar Pendidikan Kewarganegaraan di SMP N 3 Ngaglik Tahun Ajaran 2012/2013. Skripsi. Program Studi Pendidikan Kewarganegaraan Fakultas Ilmu Sosial Universitas Negeri Yogyakarta. 
Neteria, F., Mulyadiprana, A., \& Respati, R. (2020). Puzzle sebagai Media Pembelajaran Inovatif dalam Mata Pelajaran IPS Bagi Guru di Sekolah Dasar. Pedadidaktika: Jurnal Ilmiah Pendidikan Guru Sekolah Dasar. Vol. 7. No. 4.

Prawira, P. A. (2013). Psikologi Pendidikan dalam Perspektif Baru. Yogyakarta: Ar-Ruzz Media.

Saputra, H. D., Ismet, F., \& Andrizal. (2018). Pengaruh Motivasi Terhadap Hasil Belajar Siswa SMK. Jurnal Inovasi Vokasional dan Teknologi. Vol. 18. No. 1.

Sunarti. \& Dalle, A. (2017). Keefektifan Penggunaan Media Gambar Puzzle dalam Keterampilan Menulis Kalimat Sederhana Bahasa Jerman Siswa Kelas XI MAN 1 Makassar. Eralingua : Jurnal Pendidikan Bahasa Asing dan Sastra. Vol. 1. No. 1.

Suratiningsih. (2021). Puzzle sebagai Solusi Peningkatan Motivasi Belajar Siswa. At-Tarbawi: Jurnal Pendidikan, Sosial dan Kebudayaan. Vol. 8. No. 1. 